J. Clin. Chem. Clin. Biochem.

Vol. 28, 1990, pp. 447-451

(C) 1990 Walter de Gruyter \& Co. Berlin · New York

\title{
Isotachophoretic Determination of Urea-Ammonium in Plasma: A Candidate Reference Method
}

\author{
By P. Pei, F.-P. Steiner and D. J. Vonderschmitt \\ Institute of Clinical Chemistry, University Hospital, Zürich, Switzerland
}

(Received July 17, 1989/April 9, 1990)

\begin{abstract}
Summary: Separation and determination of sample constituents by capillary isotachophoresis are entirely based on physical phenomena. The method has therefore been proposed as a universal reference method for ionic constituents. The present paper shows that even neutral species can be adequately determined after suitable preceding reactions. Urea was completely hydrolysed by urease (EC 3.5.1.5) to ammonia and bicarbonate, followed by direct measurement of the ammonium ion concentration by capillary isotachophoresis. Standard Reference Material No. 912a urea (National Bureau of Standards) was used as a primary standard. The analytical linear range of the method extends to $64 \mathrm{mmol}$ urea per litre. The precision of the method was in the range of $1.05-2.64 \%(\mathrm{CV})$ and the analytical recovery of added urea was excellent $(99.4 \%$, SD $1.13 \%$ ). Further proof of accuracy was obtained by analysing the NBS human reference serum (standard reference material 909). The mean result by the capillary isotachophoretic method, $9.52 \pm 0.085 \mathrm{mmol} / \mathrm{l}$, agrees well with the reference value, $9.64 \mathrm{mmol} / \mathrm{l}$. The results obtained by capillary isotachophoresis showed good agreement with those obtained by the coupled-enzyme method $(r=0.995)$.
\end{abstract}

\section{Introduction}

Capillary isotachophoresis is an electrophoretic separation technique. In general, its major advantages are specificity, accuracy and simplicity. However, there are several disadvantages: need of special equipment for the analysis and lower sensitivity (quantitative detection limit of $5 \times 10^{-10} \mathrm{~mol}$ ) than chromatographic methods. Therefore it has not yet been widely used in clinical chemistry. It is a purely physical method separating different ionic species according to their electrophoretic mobilities. Since the experimental conditions influencing the electric mobility (e.g. $\mathrm{pH}$, complexing counter ions, temperature) can easily be controlled, isotachophoresis yields highly reproducible results for a wide range of concentrations. In addition, and most important, the isotachophoretic technique shows no matrix effect (e.g. plasma interferences from high bilirubin, lipid and haemoglobin). Proteins, which must in general be removed for chromatographic techniques, do not interfere with other ionic species if the $\mathrm{pH}$ and ionic strength of the electrolytes are appropriate. The use of unphysiological ionic compounds as internal standards is yet another advantage of this technique. For all these reasons capillary isotachophoresis seems to be an ideal candidate reference method for a number of compounds. A candidate reference method should have a well defined theoretical basis and high accuracy and precision. Lemmens et al. proposed the use of this technique as a reference method for sodium (1). Under suitable conditions, e. g. leading ion with a high mobility and a terminating ion which has a very low mobility, a number of anionic and cationic species can be adequately quantified. This is shown by our recent reports on separation and measurement of anionic and cationic constituents in urine $(2,3)$. On the other hand, by optimizing the electrolytes, it is possible to choose leading and terminating ions with mobilities very close to those of the sample ions. By this technique it is easier to separate a specific compound in a complex mixture, and it becomes possible to avoid interfering substances. 
This paper illustrates that the method is by no means limited to the determination of ionic components, and that it is easily possible to design reference methods for a non-ionized metabolite, if a suitable and well defined reaction is available to transform the metabolite into a measurable ionic form.

In the clinical laboratory, plasma or serum urea is usually determined by simple colorimetric $(4-6)$ or enzymatic methods $(7,8)$. Such methods often lack specificity and their accuracy is limited in the presence of higher concentrations of bilirubin or haemoglobin or in lipaemic samples. A study group on urea of the American Association for Clinical Chemistry has recommended an end-point coupled-enzyme method, which is rapid and very specific, as a candidate reference method for urea determination in serum (9). The following procedure is also based on the specific urea reaction.

\section{Materials and Methods}

\section{Reagents}

All reagents used were of analytical grade, and water was distilled twice in Pyrex glass. Standard urea (Standard Reference Material No. 912a, purity $99.9 \%$ ) and the certified reference preparation of human serum (Standard Reference Material No. 909) were obtained from the U.S. National Bureau of Standards (NBS), Washington, D. C., USA. Control Sera Precinorm ${ }^{\circledR} \mathrm{U}$, Precipath ${ }^{\circledR} \mathrm{U}$ and Calibrator were from Boehringer Mannheim GmbH, Mannheim, West Germany. Urease (75 $\mathrm{U} / \mathrm{mg}$; from jack beans) and tetraethylammonium bromide were from Fluka AG, Buchs, Switzerland.

\section{Apparatus}

We used a Shimadzu capillary-type isotachophoretic analyzer IP-2A (Shimadzu Corporation, Tokyo, Japan) equipped with a potential gradient detector and a UV $(254 \mathrm{~nm})$ detector. The human sera were analysed in a two-column isotachophoretic analyzer at an operating current of $300 \mu \mathrm{A}$ in the preseparation column $(1.0 \mathrm{~mm} \mathrm{I}$. D.) and $125 \mu \mathrm{A}$ in the analytical column $(0.5 \mathrm{~mm}$ I. D.). The samples were injected by Hamilton microsyringes (volumes $0.1-5 \mu \mathrm{l}$ ). The isotachophoretic patterns for these samples were recorded at a chart speed of $1.0 \mathrm{~cm} / \mathrm{min}$. The data processor used was the Isotachopac I-E1B (Shimadzu Corporation, Kyoto, Japan), which calculated the intervals between peaks (zone length), potential gradient values and time between two arbitrary potential values. To compare isotachophoretic results with the coupled-enzyme method we used the Hitachi Model 737 Automatic Analyzer. The urea assay kit, urea (BUN kin.) for BM/Hitachi System 737 was purchased from Boehringer Mannheim GmbH, Mannheim, West Germany.

\section{Procedure}

Electrolyte systems and other operational conditions are summarized in table 1 . To increase the experimental performance, $0.20 \mathrm{~g} / 1$ hydroxypropylmethylcellulose was used as a viscous additive. The leading electrolyte was a methanolic solution of tetramethylammoniumhydroxide, $10 \mathrm{mmol} / \mathrm{l}$, adjusted to $\mathrm{pH}$ 5.62 with glacial acetic acid. The terminating electrolyte was adjusted to pH 5.80 with glacial acetic acid. A urease/tetraethylammonium bromide solution was prepared by dissolving $0.20 \mathrm{~g}$ of the commercial urease preparation in $100 \mathrm{ml} 20 \mathrm{mmol} / 1$
Tab. 1. Operational system for the determination of urea in plasma.

\begin{tabular}{|c|c|c|}
\hline $\begin{array}{l}\text { Para- } \\
\text { meter }\end{array}$ & Leading electrolyte & $\begin{array}{l}\text { Terminating } \\
\text { electrolyte }\end{array}$ \\
\hline Solvent & $\begin{array}{l}950 \mathrm{ml} / 1 \mathrm{methanol} / \\
\text { water }\end{array}$ & $\begin{array}{l}950 \mathrm{ml} / \mathrm{l} \text { methanol/ } \\
\text { water }\end{array}$ \\
\hline Cation & $\begin{array}{l}10 \mathrm{mmol} / \mathrm{l} \text { tetramethyl- } \\
\text { ammonium }\end{array}$ & $20 \mathrm{mmol} / 1$ sodium \\
\hline $\begin{array}{l}\text { Counter } \\
\text { ion }\end{array}$ & $\begin{array}{l}\text { acetate, } 168 \mathrm{mmol} / \mathrm{l} \\
\text { acetic acid }\end{array}$ & $\begin{array}{l}\text { acetate, } 140 \mathrm{mmol} / 1 \\
\text { acetic acid }\end{array}$ \\
\hline Additives & $\begin{array}{l}0.20 \mathrm{~g} / 1 \text { hydroxypropyl- } \\
\text { methylcellulose } \\
8.0 \mathrm{~g} / 1 \text { Triton } \mathrm{X}-100\end{array}$ & none \\
\hline $\mathrm{pH}$ & 5.62 & 5.80 \\
\hline
\end{tabular}

tetraethylammonium bromide solution. Human plasma or urea standard $(300 \mu \mathrm{l})$ and urease/tetraethylammonium bromide solution $(300 \mu \mathrm{l})$ were mixed and the mixture allowed to stand for $15 \mathrm{~min}$ at room temperature. Without further pretreatment, $1.0 \mu \mathrm{l}$ of the sample was injected into the isotachophorectic analyzer. The ratio of the zone length of ammonium $\left(\mathrm{NH}_{4}^{+}\right)$ (derived from urea) to the zone length of the internal standard tetraethylammonium was calculated. Figure 1 shows a typical example of the resulting isotachopherogram of a plasma sample. With a constant sample volume the concentration of urea was determined from the zone length ratio $\mathrm{NH}_{4}^{+}$/ $\mathrm{N}\left(-\mathrm{CH}_{2}-\mathrm{CH}_{3}\right)_{4}^{+}$by interpolation from the standard curve. The calibration plot for urea was linear over the whole range used in these experiment $\left(\mathrm{r}^{2}=1.000\right)$ and no duplicate measurements were made. The analysis time was about $20 \mathrm{~min}$.

\section{Results}

\section{Linearity}

The linearity of the method was determined from eight urea concentrations, $0.5,1.0,2.0,4.0,8.0 .16 .0$, 32.0 and $64.0 \mathrm{mmol} / 1$ after 2-fold dilution with urease/ tetraethylammonium bromide solution. Each diluted standard was analysed twice. In figure 2 , the ratio of the zone length of $\mathrm{NH}_{4}^{+} / \mathrm{N}\left(-\mathrm{CH}_{2}-\mathrm{CH}_{3}\right)_{4}^{+}$is plotted against the urea concentration.

\section{Precision and accuracy}

The within-day variation (CV) obtained by assaying three commercial lyophilized control sera 15 times each in one run, ranged from $1.05-1.96 \%$. The between-day variations for the same samples assayed once each in 13 different runs ranged from 1.98$2.64 \%$ (tab. 2). The proof of accuracy was obtained by analysing repeatedly the same commercial control sera and the NBS human reference serum. The target values of control sera quoted by Boehringer Mannheim were determined by the coupled-enzyme method; the analysis of this reference material was certified by NBS after assay by isotope dilution mass spectrometry (tab. 3). 


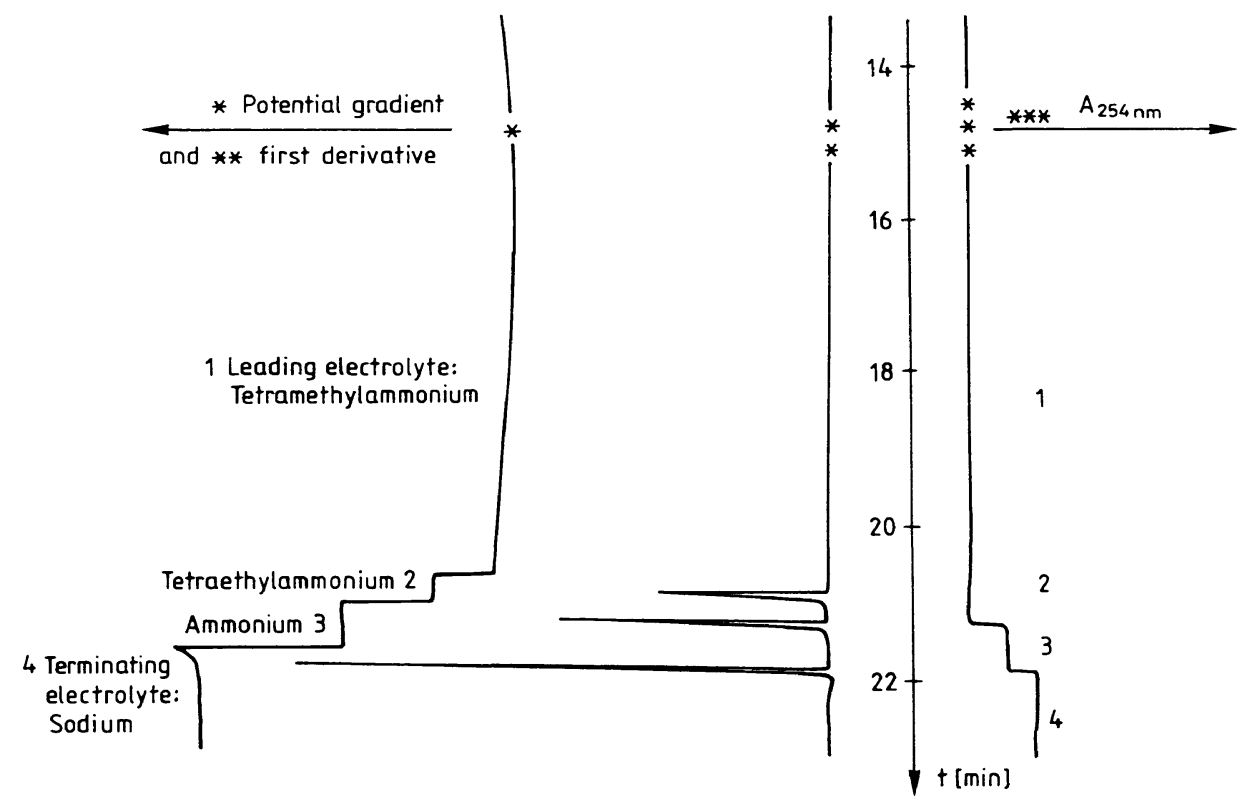

Fig. 1. Isotachopherogram of a human plasma.

tetramethylammonium $=$ leading ion, sodium $=$ terminating ion, tetraethylammonium $=$ internal standard; ammonium $=$ ammonium of urea formed by the urease reaction;

sample ions potassium, calcium, magnesium etc. have lower effective mobility than sodium under the operational conditions (tab. 1).

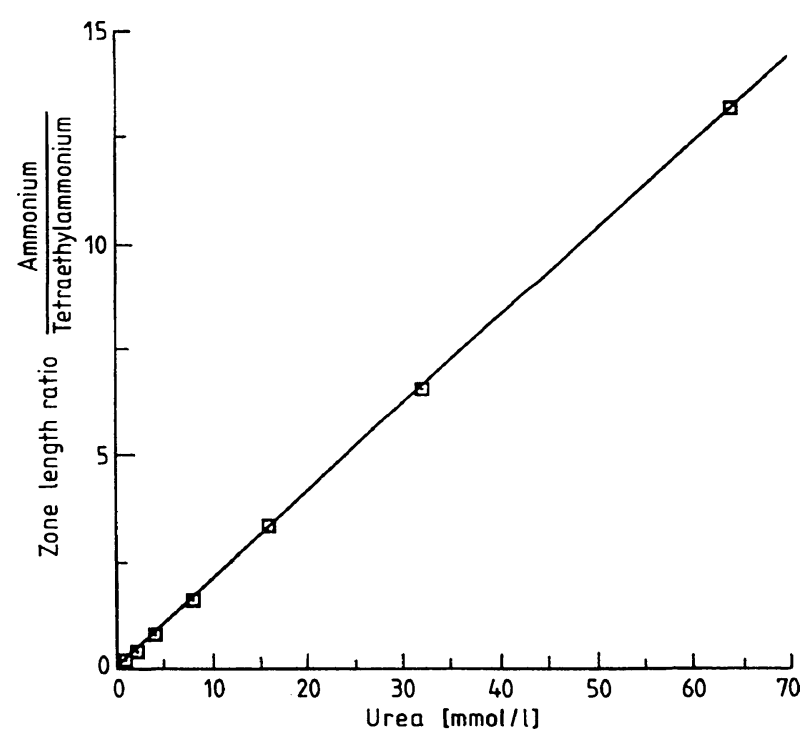

Fig. 2. Linearity of analysis of urea.

One microlitre of the urea standards (concentrations ranging from 0.5 to $64.0 \mathrm{mmol} / \mathrm{l}$ ) diluted $1: 1$ with urease/tetraethylammonium bromide solution were analysed and no duplicate measurements were made. linear regression: $\mathrm{y}=0.00632+0.20615 \mathrm{x}(\mathrm{mmol} / \mathrm{l})$; $\mathrm{r}=0.99999$

\section{Analytical recovery}

To estimate the accuracy of the method, we performed a recovery experiment. We evaluated analytical recovery of the present method by dissolving $0.15-$ $0.60 \mathrm{mmol}$ of solid urea in $50.0 \mathrm{ml}$ of each of the four different pooled plasmas. Recovery was calculated by dividing the difference between mean values $(n=5)$,
Tab. 2. Precision of analysis of urea ( $\mathrm{mmol} / \mathrm{l})$.

Results are mean \pm SD of determination with three control sera. One microlitre of the control sera after $1: 1$ dilution with urease solution was analysed repeatedly.

\begin{tabular}{|c|c|c|c|c|}
\hline \multirow[t]{2}{*}{$\begin{array}{l}\text { Control } \\
\text { serum }\end{array}$} & \multicolumn{2}{|l|}{$\begin{array}{l}\text { Within-day } \\
(\mathrm{n}=15)\end{array}$} & \multicolumn{2}{|l|}{$\begin{array}{l}\text { Between-day } \\
(\mathrm{n}=13)\end{array}$} \\
\hline & $c, \mathrm{mmol} / \mathrm{l}$ & $\begin{array}{l}\mathrm{CV} \\
\%\end{array}$ & $c, \mathrm{mmol} / \mathrm{l}$ & $\begin{array}{l}\text { CV, } \\
\%\end{array}$ \\
\hline Precinorm U & $9.35 \pm 0.098$ & 1.05 & $9.34 \pm 0.218$ & 2.33 \\
\hline Precipath U & $23.97 \pm 0.350$ & 1.46 & $23.81 \pm 0.628$ & 2.64 \\
\hline Calibrator* & $17.39 \pm 0.341$ & 1.96 & $16.85 \pm 0.334$ & 1.98 \\
\hline
\end{tabular}

* Calibrator for automated systems

Tab. 3. Urea concentrations $(\mathrm{mmol} / \mathrm{l})$ determined in the reference sera.

\begin{tabular}{lrr}
\hline Control serum & Found $( \pm$ SD) & \multicolumn{2}{c}{ Target value $( \pm$ SD) } \\
\hline Precinorm U & $9.35 \pm 0.098$ & $9.4 \pm 0.45$ \\
Precipath U & $23.97 \pm 0.350$ & $25.3 \pm 1.25$ \\
Calibrator & $17.39 \pm 0.341$ & 17.1 \\
Human refer- & $9.52 \pm 0.085$ & 9.64 \\
ence serum** & &
\end{tabular}

** Human reference serum (Standard Reference Material No. 909) was obtained from the National Bureau of Standards, Washington, DC.

The found values were obtained from within-day values (tab. 2).

before and after addition of urea, by the added urea concentration, and multiplying by 100 (tab. 4). The results of the analytical recovery of added urea was excellent (mean 99.4\%, SD 1.1\%). 
Tab. 4. Analytical recovery of urea added to different pooled plasma.

\begin{tabular}{|c|c|c|c|c|}
\hline \multirow[t]{2}{*}{ Specimen } & \multicolumn{3}{|c|}{ Urea concentration, $\left.\mathrm{mmol} / \mathrm{l}^{\mathrm{a}}\right)(\mathrm{n}=5)$} & \multirow{2}{*}{$\begin{array}{l}\text { Recov- } \\
\text { ery, } \\
\%^{c} \text { ) }\end{array}$} \\
\hline & $\begin{array}{l}\left.\text { Initial }^{b}\right) \\
( \pm S D)\end{array}$ & Added & $\begin{array}{l}\text { Found } \\
( \pm S D)\end{array}$ & \\
\hline $\begin{array}{l}\text { Pooled } \\
\text { plasma } 1\end{array}$ & $7.51 \pm 0.22$ & 12.15 & $19.67 \pm 0.38$ & 100.08 \\
\hline $\begin{array}{l}\text { Pooled } \\
\text { plasma } 2\end{array}$ & $8.44 \pm 0.06$ & 10.19 & $18.41 \pm 0.14$ & 97.84 \\
\hline $\begin{array}{l}\text { Pooled } \\
\text { plasma } 3\end{array}$ & $9.08 \pm 0.07$ & 12.00 & $20.93 \pm 0.70$ & 98.75 \\
\hline $\begin{array}{l}\text { Pooled } \\
\text { plasma } 4\end{array}$ & $7.32 \pm 0.22$ & 6.00 & $13.39 \pm 0.19$ & 101.17 \\
\hline $\begin{array}{l}\text { Pooled } \\
\text { plasma } 4\end{array}$ & $7.32 \pm 0.22$ & 3.00 & $10.30 \pm 0.19$ & 99.33 \\
\hline
\end{tabular}

a) Means of five values.

b) The initial values before urea was added.

c) The found values minus initial values divided by added urea values and multiplied by 100 .

\section{Comparison of methods}

The results of plasma urea determinations by the capillary isotachophoretic procedure were compared by linear regression analysis with those obtained by the coupled-enzyme method (fig. 3). The regression equation for the comparison was $\mathrm{y}=0.2225 \mathrm{mmol} / \mathrm{l}$ $+0.9554 x(n=37, r=0.995)$. The comparison of the results shows good agreement.

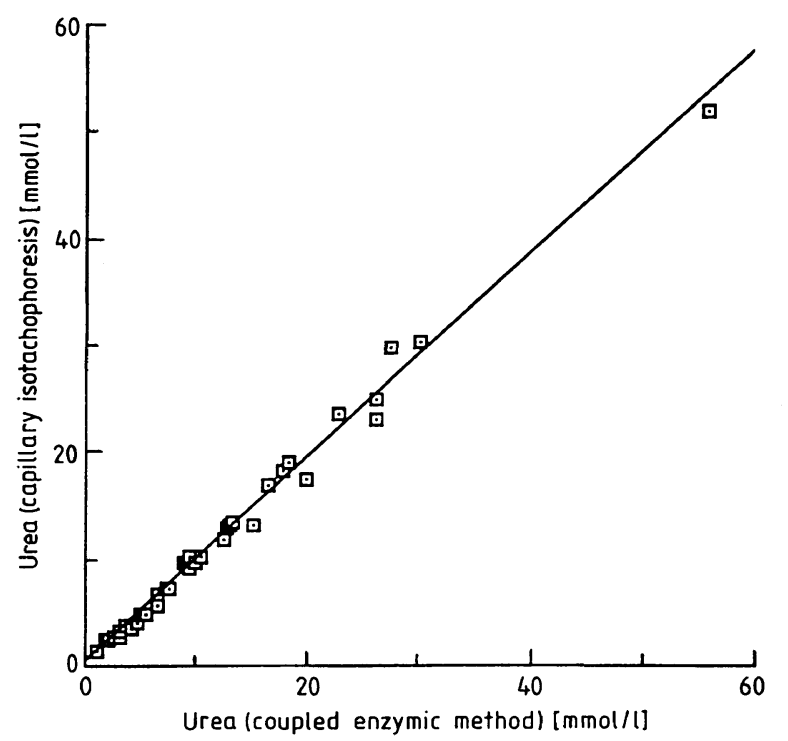

Fig. 3. Comparison of results for urea in patients' specimens as obtained by capillary isotachophoresis (y) and coupled enzymic $(\mathrm{x})$ method. The linear regression function is $y=0.22251 \mathrm{mmol} / 1+0.95541 \mathrm{x}$; the coefficient of correlation is $r=0.995$; the number of samples is $\mathrm{n}=37$.

\section{Interference studies}

The specificity of the present method was checked with a number of cationic constituents (9). The following cations did not interfere, because their effective mobilities are all lower than the effective mobility of the sample ion ammonium: $\mathrm{Na}^{+}, \mathrm{Li}^{+}, \mathrm{Cs}^{+}, \mathrm{Rb}^{+}, \mathrm{Tl}^{+}$, $\mathrm{Ca}^{2+}, \mathrm{Mg}^{2+}, \mathrm{Cu}^{2+}, \mathrm{Zn}^{2+}, \mathrm{Fe}^{2+}, \mathrm{Pb}^{2+}, \mathrm{Cd}^{2+}, \mathrm{Al}^{3+}$, creatinine- $\mathrm{H}^{+}$, creatine- $\mathrm{H}^{+}$, histamine- $\mathrm{H}^{+}$, glycine$\mathrm{H}^{+}$, serine $-\mathrm{H}^{+}$, lysine- $\mathrm{H}^{+}$, histidine $-\mathrm{H}^{+}$, arginine $-\mathrm{H}^{+}$, guanidine- $\mathrm{H}^{+}$and $\beta$-alanine- $\mathrm{H}^{+}$. Even strongly lipaemic or haemolytic or icteric plasma did not interfere with the determination of urea, because capillary isotachophoresis is an electrophoretic separation technique and not a photometric method. In this respect, capillary isotachophoresis is very appropriate as a reference method in clinical chemistry.

\section{Discussion}

The most common method for determination of plasma urea is the measurement of the ammonia formed by the urease reaction, using a coupled-enzyme system employing an NAD/NADH indicator reaction $(10,11)$. The present method allows measurement of $\mathrm{NH}_{4}^{+}$and, indirectly, of urea after its hydrolysis by urease. Interference from endogenous ammonia with the urea determination in plasma is generally negligible: the normal ranges of plasma urea and ammonia are $2.5-7.5 \mathrm{mmol} / \mathrm{l}$ and $11-55 \mu \mathrm{mol} / \mathrm{l}$, respectively.

However, for the determination of urinary urea by capillary isotachophoresis, the total ammonium after the addition of urease and ammonium before addition of urease must be measured. The urea concentration is the difference between the ammonium concentrations before and after the addition of urease.

In clinical chemistry, traditionally one aims at a specific determination of each single parameter in the matrix (e.g. by a photometric method) rather than determination of constituents after separating them. However, the accuracy and specificity of photometric methods are usually limited by the presence of coloured or interfering substances (e. g. drugs), the complexity of the procedure, and the narrow analytical range of component concentration. Capillary isotachophoretic is a classical analytical technique, which separates the different constituents of a mixture and then measures the amount or concentration of the separated single substance. Depending on accuracy, precision and specificity, the classical analytical methods were often proposed as definitive methods (e.g. isotope dilution mass spectrometry) and reference methods (e.g. GC and HPLC) in clinical chemistry 
$(12,13,14,15)$. The definition and the analytical procedure of a reference method and the reference materials in clinical chemistry were comprehensively documented by Stamm $(16,17)$ and Tietz $(18)$. We evaluated our capillary isotachophoresis method in terms of analytical recovery, precision, accuracy, absence of interference, and comparison with a coupledenzyme method.

Separation and quantification of cationic species in aqueous solution and especially in biological body fluids present a formidable problem. For example, the mobilities $\left(\mathrm{cm}^{2} / \mathrm{V} \cdot \mathrm{s}\right)$ of $\mathrm{K}^{+}$and $\mathrm{NH}_{4}^{+}$in aqueous

\section{References}

1. Lemmens, A. A. G., Reijenga, J. C., Everaerts, F. M., Janssen, R. T. P., Hulsman, J. A. R. J. \& Meijers, C. A. M. (1985) Isotachophoresis as a candidate reference method in analytical chemistry. Determination of sodium in serum. J. Chromatogr. 320, 193-197.

2. Pei, P. \& Vonderschmitt, D. J. (1987) Simultaneous determination of chloride, sulphate, orthophosphate and organic acids in human urine by capillary isotachophoresis. J. Clin. Chem. Clin. Biochem. 25, 253-259.

3. Pei, P. \& Vonderschmitt, D. J. (1988) Simultaneous determination of the most abundant cationic species in human urine by capillary isotachophoresis. J. Clin. Chem. Clin. Biochem. 26, $91-99$.

4. Henry, R. J., Cannon, D. C. \& Winkelmann, J. W. (1974) Clinical Chemistry, Principles and Technics, 2nd ed. New York, Harper \& Row Publishers Inc., pp. 504-506.

5. Faulkner, W. R. \& Meites, S. (eds.) (1982) Selected methods of clinical chemistry, vol. 9, Washington D.C. American Association for Clinical Chemistry, pp. 365-373.

6. KDA Application notes (1983) American Monitor Corporation, Indianapolis, Indiana.

7. Patton, C. J. \& Couch, S. R. (1977) Spectrophotometric and kinetics investigation of the Berthelot reaction for determination of ammonia. Anal. Chem. 49, 464-469.

8. Lespinas, F., Dupuy, G., Revol, F. \& Aubry, C. (1989) Enzymic urea assay: a new colorimetric method based on hydrogen peroxide measurement. Clin. Chem. 35, 654658.

9. Sampson, E. J., Baird, M. A., Burtis, C. A., Smith, E. M. Witte, D. L. \& Bayse, D. D. (1980) A coupled-enzyme equilibrium method for measuring urea in serum: optimization and evaluation of the AACC Study Group on Urea candidate reference method. Clin. Chem. 26, 816-826.

10. Talke, H. \& Schubert, G. E. (1965) Enzymatische Harnstoffbestimmung in Blut und Serum im optischen Test nach Warburg. Klin. Wochenschr. 43, 174-175. solution are about the same, but in methanolic solution their mobilities differ considerably. However, the effective mobilities of ammonium and potassium were very close to one another. Using Triton $\mathrm{X}-100$ as a nonionic complex-forming agent, the appropriate changes in ionic mobilities were established (3). The specificity of the present method for urea determination was evaluated by determinating the effective mobilities of various cationic species. None of the cationic species was found to have a mobility similar to that of ammonium. The mobilities of all the above cations are lower than that of ammonium, and none of them interfered with the present method.

11. Tiffany, T. O., Jansen, J. M., Burtis, C. A., Overton, J. B. \& Scott, C. D. (1972) Enzymatic kinetic rate and end-point analysis of substrate, by use of a GeMSAEC fast analyzer. Clin. Chem. 18, 829-840.

12. Welch, M. J., Cohen, A., Hertz, H. S., Ruegg, F. C., Schaffer, R., Sniegooski, L. T. \& White, V. E. (1984) Determination of serum urea by isotope dilution mass spectrometry as a candidate definitive method. Anal. Chem. 56, 713719.

13. Welch, M. J., Cohen, A., Hertz, H. S., Ng, K. J., Schaffer, R., Van Der Lijn, P. \& White, V. E. (1986) Determination of serum creatinine by isotope dilution mass spectrometry as a candidate definitive method. Anal. Chem. 58, 16831685 .

14. Derks, H. J. G. M., van Heinigen, A. \& Koedam, H. C. (1985) Gas-chromatographic determination of cholesterol in serum: candidate reference method. Clin. Chem. 31, $691-694$.

15. Schumann, G. (1986) Referenzmethode für die KreatininBestimmung durch Hochdruckflüssigkeits-Chromatographie. Fresenius Z. Anal. Chem. 324, 209-211.

16. Stamm, D. (1982) A new concept for quality control of clinical laboratory investigations in the light of clinical requirements and based on reference method values. J. Clin. Chem. Clin. Biochem. 20, 817-824.

17. Stamm, D. (1979) Reference materials and reference methods in clinical chemistry. J. Clin. Chem. Clin. Biochem. 17, $283-297$

18. Tietz, N. W. (1979) A model for a comprehensive measurement system in clinical chemistry. Clin. Chem. 25, 833839.

Prof. Dr. D. J. Vonderschmitt

Director, Institute of Clinical Chemistry

University Hospital

CH-8091 Zürich 
